University of Nebraska - Lincoln

DigitalCommons@University of Nebraska - Lincoln

Textile Society of America Symposium

Proceedings

Textile Society of America

$10-2020$

\title{
Plants in the Tapestry (Literally)
}

Ann H. Peters

Adriana Soldi S.

Follow this and additional works at: https://digitalcommons.unl.edu/tsaconf

Part of the Art and Materials Conservation Commons, Art Practice Commons, Fashion Design Commons, Fiber, Textile, and Weaving Arts Commons, Fine Arts Commons, and the Museum Studies Commons

This Article is brought to you for free and open access by the Textile Society of America at DigitalCommons@University of Nebraska - Lincoln. It has been accepted for inclusion in Textile Society of America Symposium Proceedings by an authorized administrator of DigitalCommons@University of Nebraska - Lincoln. 


\section{Plants in the Tapestry (Literally)}

\section{Ann H. Peters and Adriana Soldi S.}

The Soldi collection and the history of Peruvian archaeology:

This brief report shares ongoing research into two textile objects that form part of a Peruvian private collection. The collection was formed in the early $20^{\text {th }}$ century by Carlos and Ana Maria Soldi, part of an extended family resident in the Ocucaje basin in the lower Ica valley (Fig. 1). The Hacienda Ocucaje was famed throughout the $20^{\text {th }}$ century for its signature wines made from grapes grown on its own lands, which were established in the early decades by expanding and modernizing the basin's irrigation system, of prehispanic origin. Both work on the irrigation infrastructure and other construction along the valley margins turned up ancient ceramics of great beauty, and the Soldi homesteads were near a chapel built on a rocky outcrop adjacent to ancient walls, where burials in the dry soil also preserved finely decorated textiles. The Truel, Rubini and Soldi families became collectors, fascinated with the beauty and preservation of this evidence of the region's history.

The Ica collections, and the Ocucaje basin in particular, attracted the attention of archaeologists. Max Uhle excavated in Ocucaje in 1899, at a time when his research was funded by Phoebe Apperson Hearst, who in 1901 founded the University of California Museum of Anthropology. The Ocucaje materials became part of the original collection of that museum, and were the subject of a style analysis by Kroeber and Strong. ${ }^{1}$ In Peru, Julio C. Tello had visited Paul Truel and others in the greater Ica region as part of a project to develop a national museum of archaeology, acquiring information that led to his excavations to research Paracas, Nasca and Wari in the $1920 \mathrm{~s}^{2}$ The Ocucaje collectors were among those most friendly and hospitable to archaeologists.

By the 1950s, the Rubini and Soldi families had also established collections, and they received a visit from William D. Strong in 1951, who excavated on the outcrop then known as "Cerro Max Uhle." A research team from the University of California, led by John H. Rowe and Dorothy Menzel, arrived in Ica in 1956 with support from the U.S.-funded Fulbright Commission, to conduct an integral study of relationships of artifact style and time in the region. The Soldi and Rubini collections provided key resources for this study. A style analysis led by Menzel and Lawrence Dawson integrated data from graduate students Dwight Wallace and Edward P. Lanning for a book on Paracas. Dawson worked with Donald Proulx and Richard Roark on their subsequent studies of Nasca style and iconography. Menzel developed both a study of style and time in the Middle Horizon and a book on the Ica, Chincha and Inca styles spanning the Late Intermediate Period, Late Horizon and early Colonial period. All these published studies focused

\footnotetext{
${ }^{1}$ Alfred L. Kroeber and William D. Strong, "The Uhle Pottery Collections from Ica, with Three Appendices by Max Uhle," University of California Publications in American Archaeology and Ethnology Vol. 21, No. 3 (1924), 95134.

2 Julio C. Tello, Paracas: Primera parte, (Lima: Institute of Andean Research, 1959). Also see Richard E. Daggett, "Introducción a las investigaciones de Julio C. Tello en la península de Paracas." In Paracas, primera parte. Julio C. Tello, obra completa, vol. 2 (Lima: Universidad Nacional Mayor de San Marcos, 2005), 53-66.
} 
on ceramic styles, but the diverse and beautiful textiles recovered in the greater Ica region have also been a principal stimulus for research.

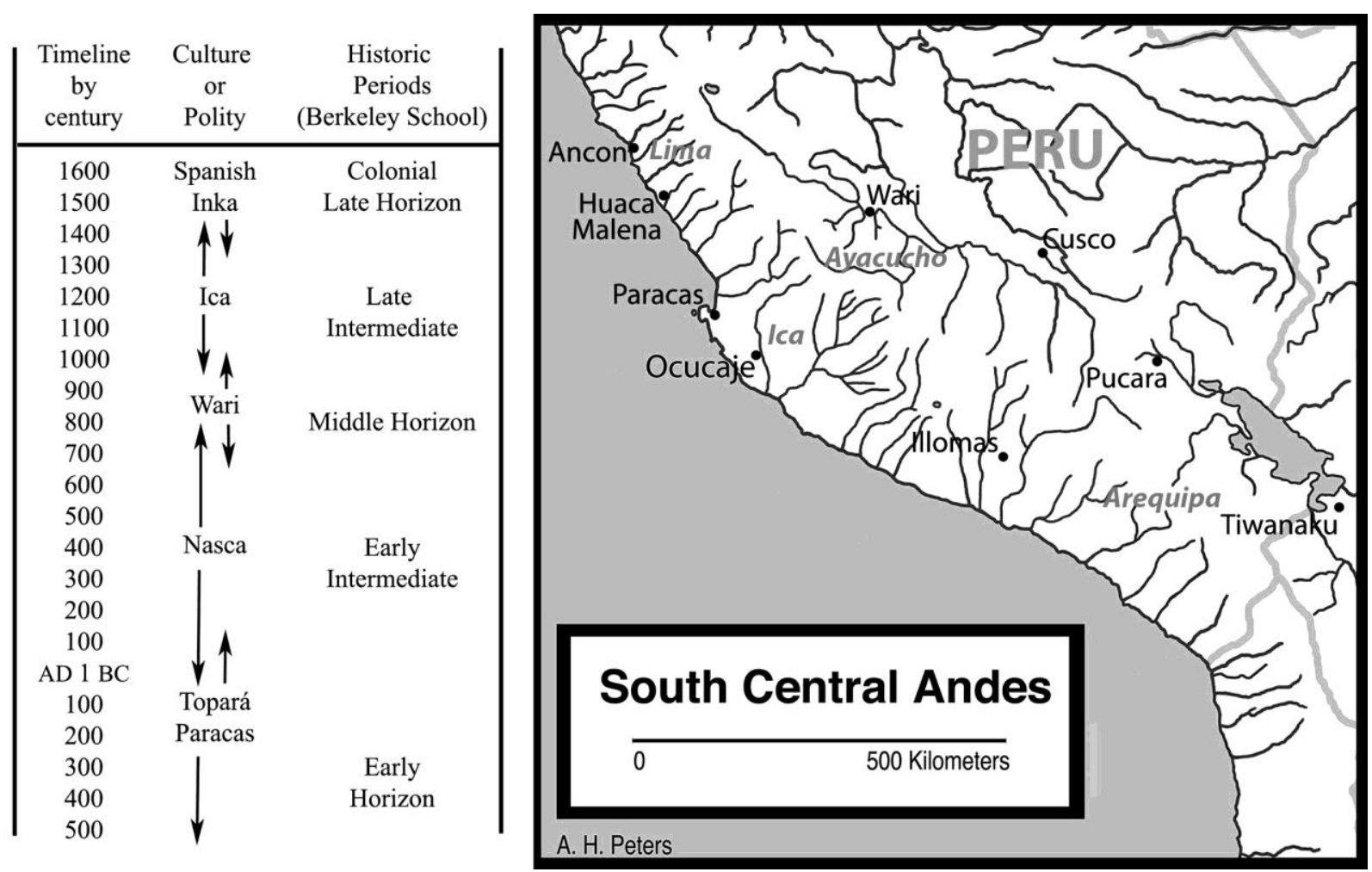

Figure 1. Historic time, sociocultural categories in Ica and their context in geographic space.

The deserts of the Pacific watershed of the central and south-central Andes offer exceptional conditions for archaeological preservation of textiles. Moreover, funerary traditions in this region have carefully preserved the bodies of the dead, wrapped in cotton shrouds layered with clothing, regalia, tools and weapons. In some cases, these have been used in life, while objects placed when new appear to have been offered during post-mortem rituals. Both Spanish and Andean chroniclers in the first eighty years after the fall of the Inca empire describe and illustrate yearly visits to pay homage to the preserved bodies of prominent ancestors, their transport on litters, and their participation in public events. ${ }^{3}$ Textiles from the Ica region of the Paracas, Nasca, Wari, Ica and Inca traditions have been the subject of research by Rebecca Carrión, Dwight Wallace, Elizabeth King, Alan Sawyer, Anne Paul, Elena Phipps, Susan Bergh, Mary Frame, Ann P. Rowe, Jeffrey Splitstoser, Nathalie Boucherie and others. Faced with such a substantial bibliography, we cite only studies directly pertinent to the artifacts analyzed here.

Most archaeological textiles and other artifacts made of organic materials come from preserved burials and ritual offerings. While most Central Andean communities continue to be comfortable with the presence of ancestral remains, they are powerful and may be dangerous - qualities which may extend to ancient artifacts. Unfortunately, they have also been subject to

\footnotetext{
${ }^{3}$ Felipe Guaman Poma de Ayala, El primer nueva corónica y buen gobierno (1615/1616) (København, Det Kongelige Bibliotek, GKS $22324^{\circ}$ ) http://www5.kb.dk/permalink/2006/poma/info/en/frontpage.htm
} 
graverobbing, expanded in the $20^{\text {th }}$ century to a huge scale driven by regional and international markets in antiquities. Huaquear - to excavate in an archaeological or sacred context - may be spurred by individual curiosity or urgent economic need, but has expanded to provoke massive destruction of regional history, including the objects themselves. Most looted objects lose all information on who they once honored, how they were placed, what else was present, and even their place of origin. During and after excavation, many are altered, damaged or destroyed.

The Soldi collection is exceptional, as it was created decades before industrial-scale looting and site destruction - in what John H. Rowe called the pre-bulldozer period of Peruvian archaeology. While most objects were purchased from or exchanged with friends and neighbors in Ocucaje and the Ica region, they have strong local or regional provenience and all have been carefully preserved for more than sixty years. In Peru it is legal to have a private collection, but it must stay in the country. Our observations form part of the cataloguing of their collection and the development of a publication that highlights some of the fascinating objects that inspired the studies of Dorothy Menzel and other colleagues. Here we examine two artifacts: to define a novel type of tapestry band, contemporary with Paracas but from a different tradition, and to closely examine a special type of container in a Wari style.

A tapestry band (approx. $100 \mathrm{BC}$ ):

This woven band has a slit tapestry structure, with warps running lengthwise hidden by the weft patterning (Fig. 2). Rectangular segments with a predominantly dark blue background are separated by vertical lines of weft in contrasting colors, spanning the width of the band. In each segment is a feline figure with frontal face and profile body, full of square spots below an arched back and above paired straight legs, traversed by bands above feet with three or four straight toes. The head is narrow, with vertical ears, solid eyes and a rectangular mouth with bared fangs. Below the head, space is filled by a large " $X$ " motif. Above the neck, a line parallel to the margin of the head, neck and back forms a "V" motif that fills that space. 

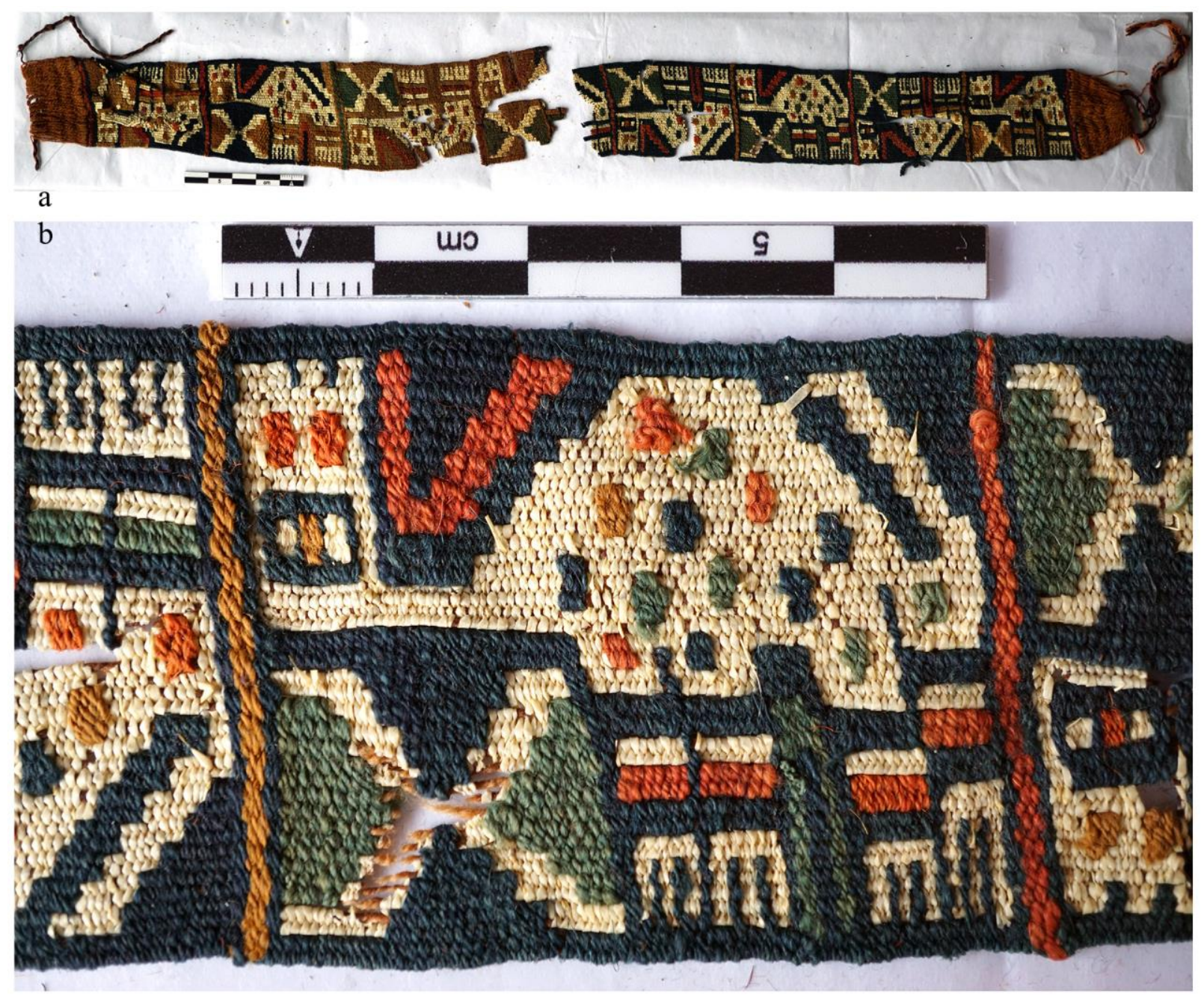

Figure 2. (a) Tapestry band of cotton, camelid hair and plant stem elements, CS1231. (b) Detail. Photos A. H. Peters.

The tapestry band had been identified by a previous researcher as "Chincha" - a famous regional power contemporary with the Inka empire. Perhaps this was due to the "X" motif, that resembles Inka symbols called Toqapu, and the profile figure with frontal head, reminiscent of some Inka or Inka-Colonial representations of a puma or other feline. However, this genre of band, its particular production techniques and its specific imagery have no known counterpart among Chincha textiles.

We noted that the spin, ply and thickness of the camelid weft yarns are more similar to decorative bands woven or embroidered in styles known as Paracas, which dominated this region more than two thousand years earlier. Hair from both wild vicuña (Vicugna vicugna) and domestic camelids similar to historic llamas and alpacas has been identified in Paracas and early Nasca textiles. ${ }^{4}$ The dyed colors of dark blue, green, golden yellow and red are typical of late Paracas and the Paracas-Nasca transition, but the prominent lustrous cream white is unusual.

\footnotetext{
${ }^{4}$ Nathalie Boucherie, Nathalie, Witold Nowik, and Dominique Cardón, "La producción tintórea Nasca: nuevos datos analíticos obtenidos sobre textiles recientemente descubiertos en excavaciones." In S. Desrosiers and P. Nuñez-Regueiro, eds. Textiles amérindiens. Regards croisés sur les couleurs. Mundo Nuevo - Nuevos Mundos, Colloques [en ligne] 2016. https://journals.openedition.org/nuevomundo/69222\#text
} 
However, on pulling out the hand lens, we are deeply surprised to see that the white feline bodies are not created with yarn. They are woven of slim, tubular reeds with a conical tip (cut at the other, lower end). We return to this topic below.

The warp yarns are a sturdy cotton in an ochre hue, one of the colors naturally present in native Andean cotton. Native South American cotton varieties are perennial small trees, still cultivated in the Amazon regions and the north coast of Peru and present on the south coast as cultigens and feral varieties found as far south as the Pica region of northern Chile. The warps have browned and become friable in some areas, particularly where the vegetal wefts are also deteriorated. This band is broken in one place, but the entire length appears to be represented.

At each end, the tapestry ends abruptly and the warps turn back, so it is a four-selvedge band. Loops of yarn similar to those used in the weft are added, warp extensions that are loosely woven with paired wefts of the same yarn. A heavier plied yarn has been passed through the end, creating a loop with an attached tie cord. This hammock-like finish is analogous, but not identical, to the ends of Paracas tradition hammock-shaped knotted nets that were probably wrapped like a headdress on the peak of a mortuary bundle. ${ }^{5}$ On the center of the band, a single motif repeats with the head always in the same direction, while the figure flips on its vertical axis. This form of symmetry is characteristic of late Paracas and early Nasca embroidered bands, compared by Mary Frame to footprints or walking motion. ${ }^{6}$

We compared this band with feline imagery on Paracas embroidered textiles and ceramics, including pieces from Ocucaje and others from the Paracas site to the north. There are many similarities in representational conventions scattered among textiles from the Ocucaje basin. Cream-white figures and "twisted strand" X motifs appear on thick sweater-like tunics of camelid hair (in simple looping), which allegedly come from Ocucaje tombs ${ }^{7}$ but were almost certainly made in contemporary Paracas-associated sites in the adjacent Andean highlands. In branches of the upper Palpa valley east of Ocucaje, sites spanning late Paracas and early Nasca are located where steep wooded valleys emerge onto high altitude grasslands. ${ }^{8}$

On the outer walls of late Paracas bowls from Ocucaje, motifs can appear within segments divided by vertical lines. These include felines with a profile body and frontal head, arched back and lifted tail, and short legs, sometimes with bands, three or four toes, and a line paralleling the back. Felines embroidered in the Broad Line mode typically have a sharply arched back, almost triangular, with a grid of spots created with diagonal stitching and paired legs with straight toes. On comparing the piece with feline imagery on a late Paracas tradition triple-cloth textile and

\footnotetext{
${ }^{5}$ Ann H. Peters, "Travels of a rayed head: textile movement and the concepts of center and periphery in the southern Andes," In W. Isbell, M. Uribe, A. Tiballi and E. P. Zegarra, eds. Images in Action: The Southern Andean Iconographic Series (Los Angeles: Cotsen Institute of Archaeology Press, University of California, 2018), 109-138. ${ }^{6}$ Mary Frame, "Motion Pictures: Symmetry as animator, classifier and syntax in the Nasca embroideries of Peru," In D. K. Washburn and D. W. Crowe, eds. Symmetry Comes of Age: The Role of Pattern in Culture (Seattle: University of Washington Press, 2004), 133-176.

${ }^{7}$ Mary Elizabeth King, Textiles and Basketry of the Paracas Period, Ica Valley, Peru. PhD. Dissertation, Department of Anthropology, University of Arizona, Tuscon (Ann Arbor: University Microfilms, 1965).

${ }^{8}$ Marcus Reindel and Johny Isla. "De Paracas a Nasca: Nuevas evidencias desde la vertiente occidental de la sierra de Lucanas, Ayacucho.” Boletín de Arqueología PUCP 25 (2018), 229-254. http://revistas.pucp.edu.pe/index.php/boletindearqueologia/article/view/21525
} 
also on its embroidered border we note that a wide range of conventions are used to depict feline imagery at the period and even combined on a single object (Fig. 3). Cats with multicolor spots appear in some early Nasca style embroideries and tapestry headbands. However, the specific forms of head and body in the Soldi Collection tapestry band differ from all of the Paracas Tradition objects in our large comparative sample.

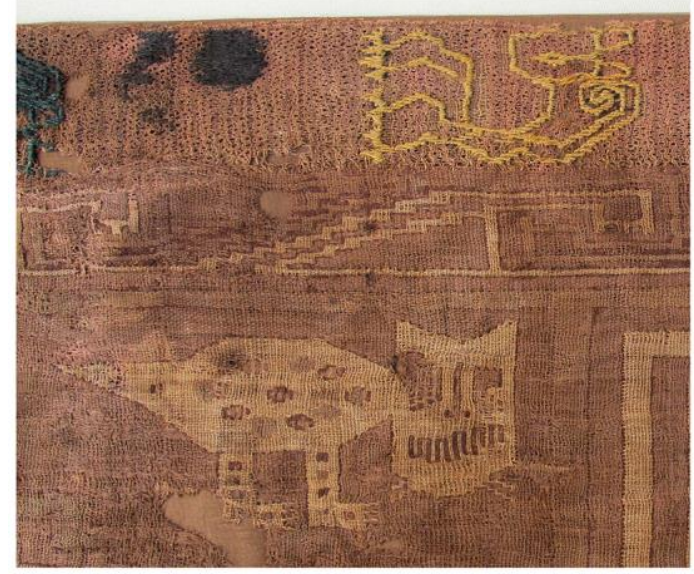

a
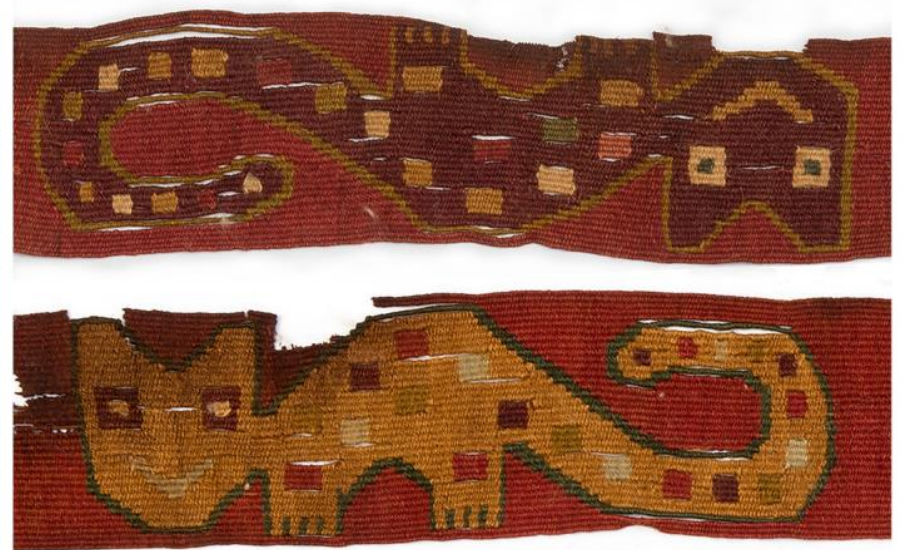

$\mathrm{b}$

Figure 3. (a) Excavated at the Paracas site, triple-cloth skirt with its embroidered border partially preserved; Museo de Sitio de Paracas, cat. MSP 0863. (b) Excavated at the Paracas site, tapestry headband (llauto) from the Necropolis of Wari Kayan, tomb 89; Museo Nacional de Antropología, Arqueología y Historia del Perú, Registro Textil 183. Photos A H. Peters.

The feline images might represent the puma (Puma concolor), whose cubs have a spotted pelage seldom retained in adulthood, or one of the smaller spotted Andean cats. The pampas cat (Leopardus colocolo) includes spotted and unspotted varieties and is a pervasive predator in coastal lomas regions of cloud forest and seasonal pasture. The elusive mountain cat (Leopardus jacobitus) has quite long hair with blurred spots and lives in high-altitude rocky places.

To our surprise, we noted a much closer match in petroglyphs (rock art) at the site of Illomas, far to the south on the route to the Chuquibamba region of Arequipa and beyond towards the highaltitude plains around Lake Titicaca. ${ }^{9}$ Feline figures at the Illomas site vary in style, but six figures pecked into boulder PAJ-001 share a set of distinctive features: narrow squared frontal heads with ears as vertical lines and gaping, often rectangular mouths; flat-bottomed bodies with paired straight legs and high arched backs, containing stripes and/or rows of spots, in one example squared; upward curving tails.

These Illoma petroglyph felines bear a striking resemblance to the representational conventions of those on our tapestry band. Objects and imagery reported from the Arequipa region are often termed Paracas or Nasca in style, terms also applied to the Illomas rock art. While some Paracas tradition and Nasca tradition objects can be found in the valleys of Ocoña, Sihuas, and Camaná, which run between the Arequipa region and the Pacific Ocean, their presence indicates recurrent communication and travel between the greater Ica region and southern neighbors that have their own strong traditions.

\footnotetext{
${ }^{9}$ Justin Jennings, Maarten Van Hoek, Willy Yépez Álvarez, Stefanie Bautista, Ronald A. San Miguel Fernández, and Giles Spence-Morrow, "Illomas: The three-thousand year history of a rock art site in southern Peru," Ñawpa Pacha 39, No. 2 (2019), 181-211: see fig. 18. https://doi.org/10.1080/00776297.2019.1635313
} 
Early Siguas is a distinct textile tradition of this region. Contemporary with Paracas, early Nasca, Pukará and early Tiwanaku, it shares with them iconographic motifs as well as textile techniques. ${ }^{10}$ The Siguas textile assemblage is known from looted objects and the fragments gleaned from looted sites, so it is not possible to describe contexts or the full range of artifacts present. However, most of the decorated textiles are woven, particularly in tapestry or in scaffolded weaving (discontinuous warp and weft). Later Siguas tapestry bands, contemporary with late Nasca and the early Middle Horizon, often have end finishes created with yarns like those used in the wefts, typically braided. There is much to learn about artifacts typical of the valleys south of Nasca, as they have too often been discussed as similar to Paracas or Nasca rather than properly described to define each regional assemblage.

Therefore, we hypothesize that the Soldi Collection tapestry band comes from the south: rather than representing a previously unknown form within the Paracas Tradition, it represents a contemporary regional tradition that interacted with Paracas. As we seek more information and artifacts to compare, we consider that this unusual use of plant material for a tapestry weft is of vital importance. Over the past year, natural history museums have not been open for research purposes in either Peru or the United States, but we can report some advances based on published botanical studies and communication with colleagues.

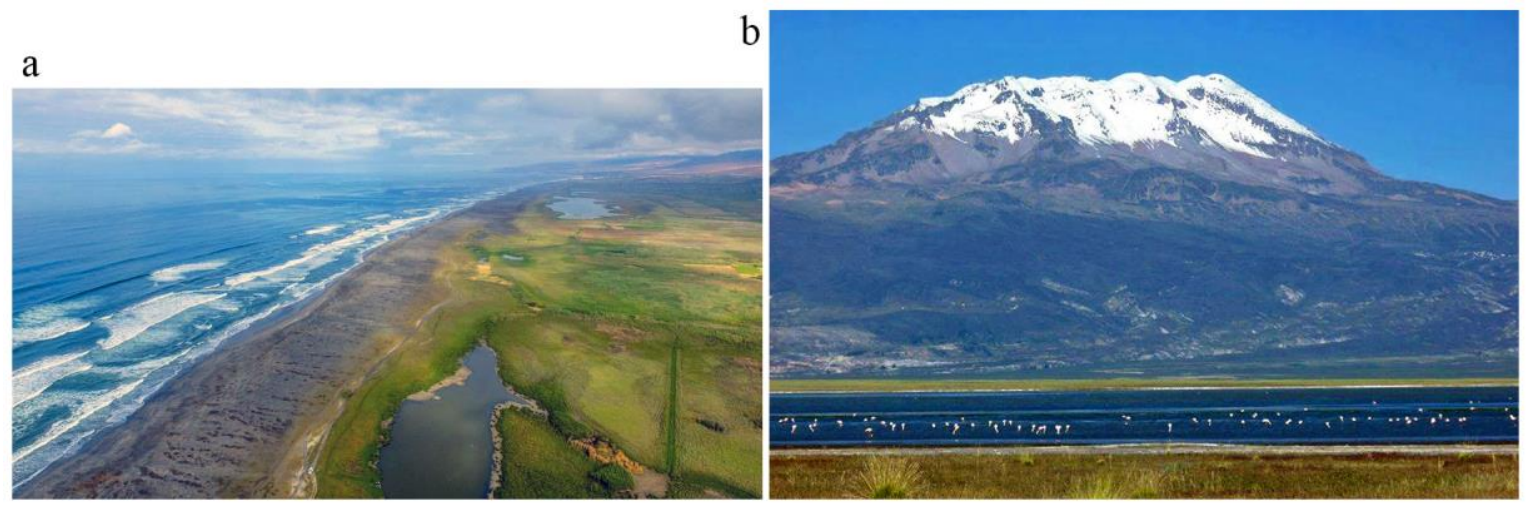

Figure 4. (a) Coastal wetlands preserved at the National Sanctuary Lagunas de Mejía, by the mouth of the Tambo river in Arequipa. (b) Lake Parinacocha and the Sara Sara volcano in the highlands of southern Ayacucho. Photo credits below. ${ }^{11}$

Reeds and grasses whose stems or leaves are suitable for weaving are found in two types of Andean wetlands (Fig. 4): high altitude lakes and wetlands in the rolling puna grasslands among the Andean peaks, or coastal wetlands that include areas where groundwater comes to the surface in springs or desert lakes and coastal lagoons parallel to the Pacific coastal beaches. Many of the same types of plants are found in both regions, although some different species are adapted to the high-altitude conditions and those at sea level. In both altitudinal zones, some bodies of water become quite saline, while others are fed by water low in mineral salts and are well drained.

\footnotetext{
${ }^{10}$ Joerg Haeberli. "Tiempo y tradición en Arequipa, Perú y el surgimiento de la cronología del tema de la deidad central," In P. Kaulicke and W. H. Isbell, (eds.), Huari y Tiwanaku: Modelos vs. Evidencias (segunda parte). Boletín de Arqueología PUCP 5 (2001), 89-137.

http://revistas.pucp.edu.pe/index.php/boletindearqueologia/article/view/2353

${ }_{11}$ Photo credits: (a) https://miqueridaarequipa.info/humedales-de-arequipa-atractivo-turistico-y-fuente-debiodiversidad/ (b) Edubucher, CC BY-SA 4.0, https://commons.wikimedia.org/w/index.php?curid=38122457
} 
Fresh water lagoons are the best sources for plants used in weaving and basketry, as those from salt waters are brittle. While most of Peru's coastal wetland ecosystems have been severely damaged, the regions of Pisco and Ica abound in desert springs, spring-fed lakes and totoral ponds, some still used for harvesting the cattails (Typha angustifolia) whose leaves have been used for millennia to weave mats. The coast of Arequipa features the historic wetlands of Camaná as well as the Lagunas de Mejía National Sanctuary at the mouth of the Tambo River, the best-preserved surviving example of these coastal ecosystems.

The botanical communities of both high-altitude and coastal wetlands have been studied by botanists at Peru's National Museum of Natural History. A highland study focuses on lake Parinacocha, ${ }^{12}$ located in the high Andes southeast of the Nasca watershed and northwest of the Illoma petroglyphs. Two coastal studies monitor the botanical community of the Pantanos de Villa, south of Lima near Pachacamac. ${ }^{13}$ A surprising variety of reeds are present, including Schoenoplectus americanus (formerly Scirpus californicus), the same bulrush that sustained the Californian basketry tradition. Still used for Andean handicrafts - and to make boats at Huanchaco on Peru's north coast and in the highlands on Lake Titicaca - this reed is far too large to be that used in our tapestry band. Finer reeds present include Cypherus Laevigatus and Eleocharis genticulata.
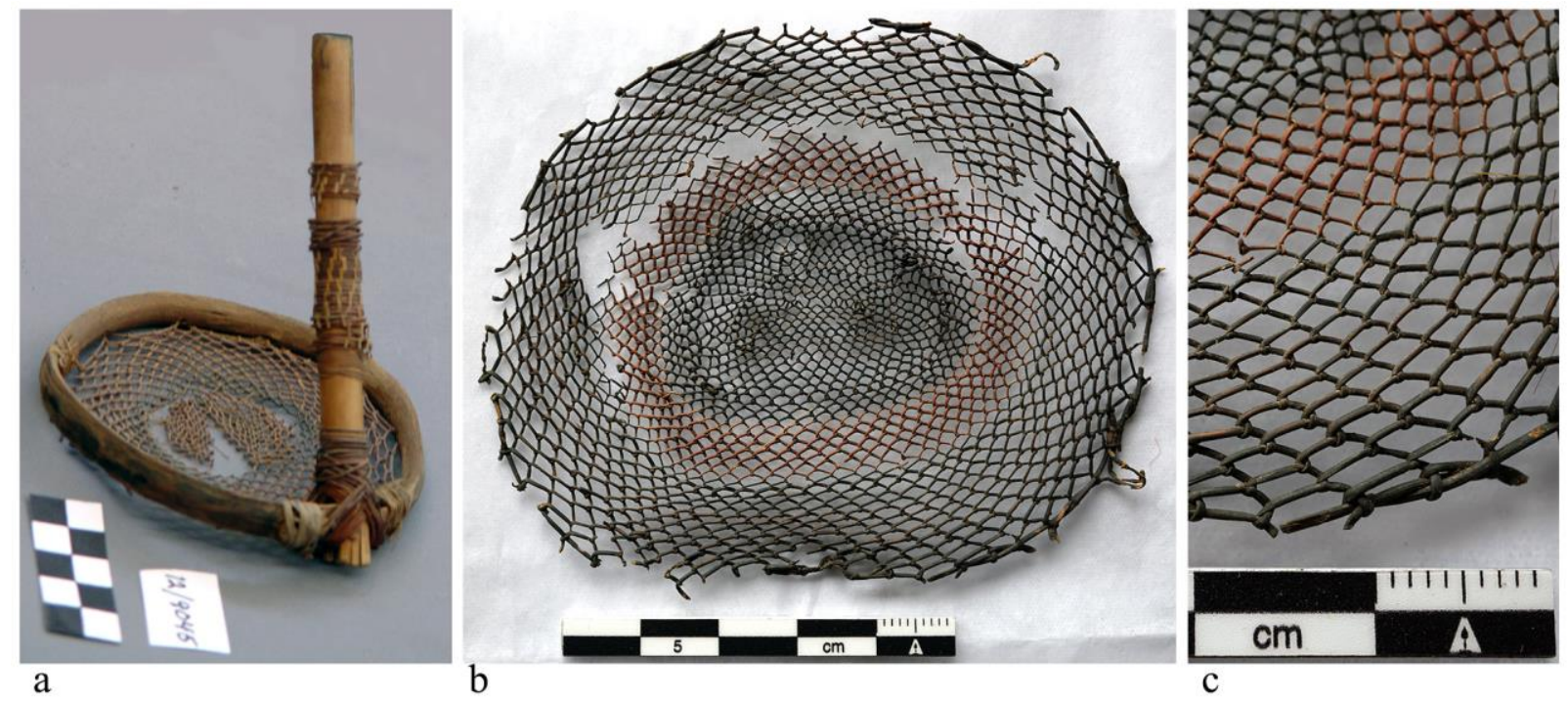

Figure 5. Scoop (colador) with a cane handle and bent wood hoop bound with bulrushes and a sieve of spiral looped netting in fine reeds dyed red and black. (a) From the Paracas site, Museo Nacional de Antropología, Arqueología y Historia del Perú, cat. 12/9045. (b) and (c) Fragmentary sieve component, CS1618.

A very fine tubular reed, even slimmer than those in this band, was used to make looped netted disks attached to a wood hoop and cane handle (Fig. 5). This artifact has been called a scoop or colador, and is found in many late Paracas tombs. Fishing enthusiasts suggest that these sieves

\footnotetext{
${ }^{12}$ José Y. Roque and Ella Karina Ramirez, "Flora vascular y vegetación de la laguna de Parinacochas y alrededores (Ayacucho, Perú)," Revista Peruana de Biología Vol. 15, No. 1 (2008) 61-72. https://sisbib.unmsm.edu.pe/BVRevistas/biologia/v15n1/contenido.htm

${ }^{13}$ Dámaso Ramirez, "Asunción Cano Estado de la diversidad de la flora vascular de los Pantanos de Villa (Lima Perú),” Revista Peruana de Biología Vol. 17, No. 1 (2010), 111-114. https://sisbib.unmsm.edu.pe/BVRevistas/biologia/v17n1/contenido.htm
} 
might have been used to gather marucha seaworms (Fam. polychaetes) from the fine sandy bottom of the shallow waters of the Bay of Paracas. ${ }^{14}$ Seaworms are used for bait to catch medium sized fishes (flounder, merluza, lorna, mullet etc.) that were netted in Paracas and Nasca times. These reeds often have been dyed, and their contrasting colors can form motifs worked in the spiral looping.

While the species of reed and its origin in a high altitude or coastal wetland remain to be determined, the cotton and camelid hair also present embody a relationship between the Andean lowland valleys and the high grassy plateaus. While camelids can live on the coast, the vicuña are a high-altitude wild species and the domesticated alpaca thrive in puna wetlands. Both the band's form and the style of its feline imagery indicate that it represents a textile tradition contemporary with Paracas but centered far to the south of Ica, so its presence in the Soldi collection is evidence of the longstanding relationships between these regions.

\section{A tubular container (c. 900 AD):}

This rigid tube is closed at one end, while the other is open (Fig. 6). It is plugged with a cork, apparently of modern manufacture, with a cylindrical perforation like those made by a drill. The exterior face of this cylindrical container is covered by a tapestry of camelid hair weft patterning divided into segments composed by images of profile or "half" faces alternating with other motifs. These include rainbow-like arches, profile heads of a raptor, and stepped diagonals with hooked frets. Each type of motif repeats four times in varying color combinations in a band that circles the tube. Colors present include black, white, red, green, pink, yellow, a light blue, light brown, darker brown and light orange. The hues vary somewhat, so perhaps several dye lots are present. The yarns are all Z-spun and S-plyed, but vary in their weight and twist.

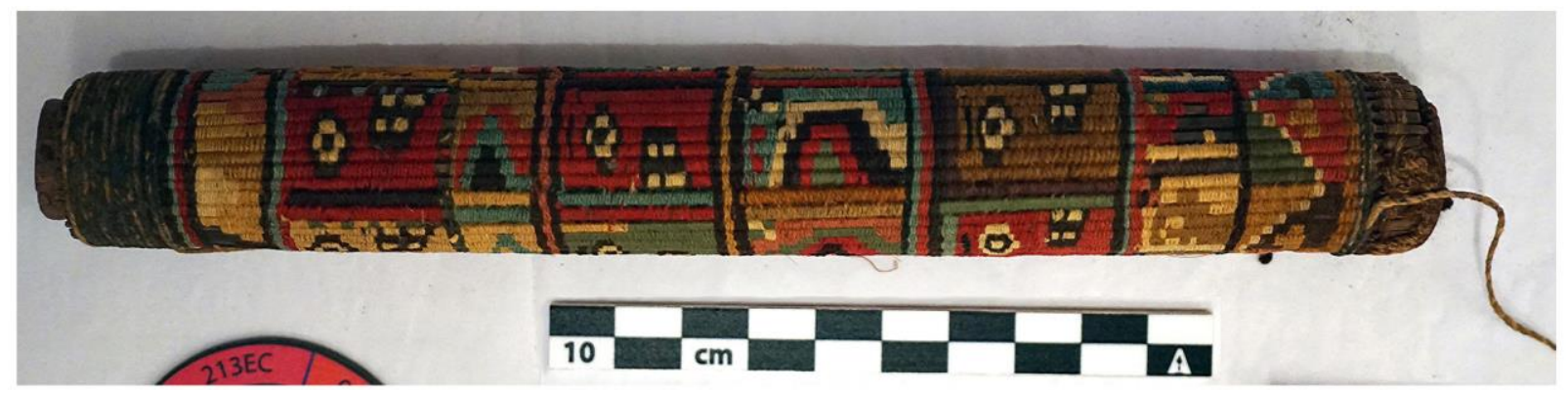

Figure 6. Tubular container covered in a panel of tapestry worked on wefts of wood splints. Photo A. H. Peters.

Three circumferential bands of faces and two of rainbow-like motifs have divisions between their segments aligned, the margins coinciding along the axis of the tube to form a grid-like pattern. At the open end, these are flanked by a circumferential band of wide diagonal stripes. At the closed end there are two bands: one repeats a motif resembling a profile raptor head as well as the rainbow arch and the other has rectangles bisected by a diagonal line with an adjacent fret motif. Neither of these bands maintains an alignment consistent with the five central registers.

Wari tapestry tunics are a garment form that defines the Middle Horizon in the central and southcentral Andes. In documented contexts, such tunics are often placed over the exterior of a mortuary bundle with a distinctive 'body' shaped like a rounded rectangle, below a separately

${ }^{14}$ Jorge Recharte, personal communication 2019. 
formed 'head' with facial features and a hairpiece or headdress elements. An interred individual lies deep within the bundle, typically accompanied by elements of regional dress, and a cotton shroud, surrounded by raw cotton fiber. That padding creates an outer bundle shape that fits the emblematic tunic it wears. ${ }^{15}$ Thus, the mortuary context has been configured to represent a relationship with the Wari state or empire, marked by architecture and artifact styles centered in the Ayacucho highlands to the southeast of Ica and extending over most of the central Andes.

While there are many styles of Wari tunics, the most standardized and widespread form has decorative bands divided into segments (Fig. 7). Each rectangular segment is divided by a diagonal line separating paired motifs, typically a profile or 'half' face and a stepped-fret motif that may include a multicolor, rainbow-like arch. Sometimes these motifs alternate with segments containing a pair of camelid heads. When on the loom, these tapestry bands ran horizontally in the weft direction, but each band of segmented imagery is vertical in the tunic as worn. Both the motifs and the bands get narrower as they approach the side seams, giving either a single decorative band or the entire tunic the illusion of cylindrical form. ${ }^{16}$ Bergh has demonstrated that the color repetitions on these 'face-fret' tunics create a pattern of stepped diagonals continuing across the long rectangles of the decorative bands.

$$
\text { a }
$$

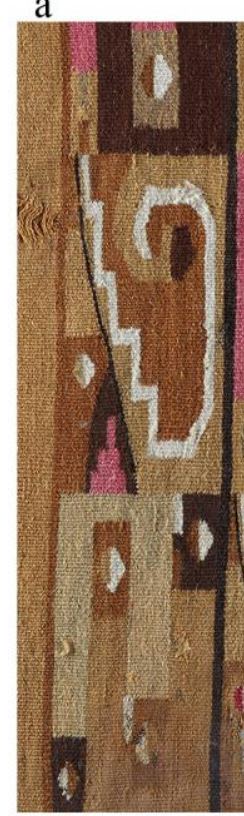

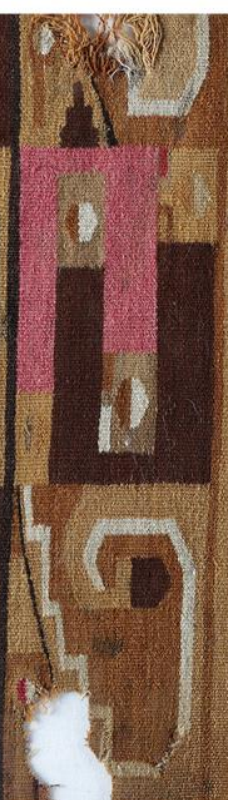

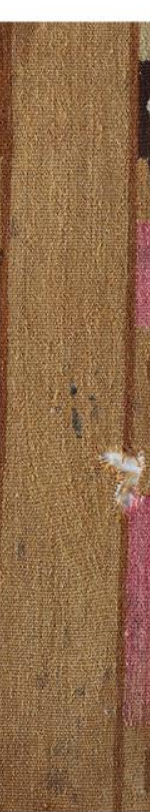

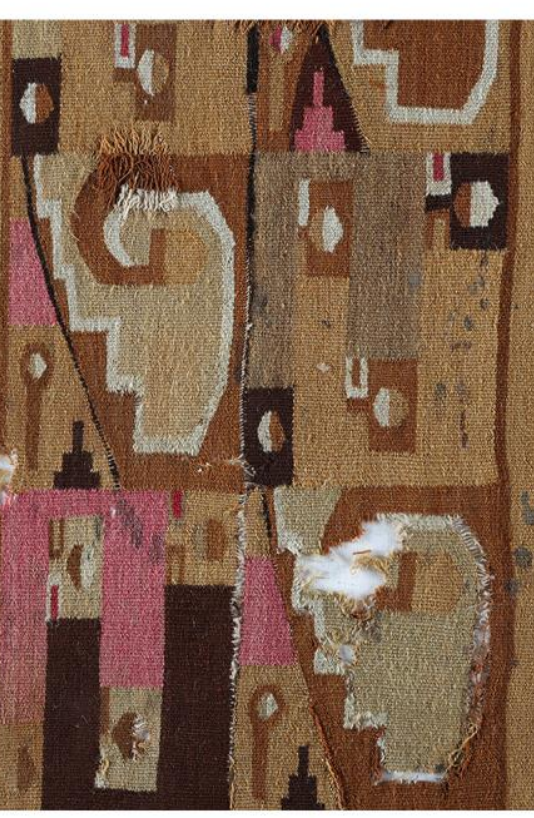

$\mathrm{b}$

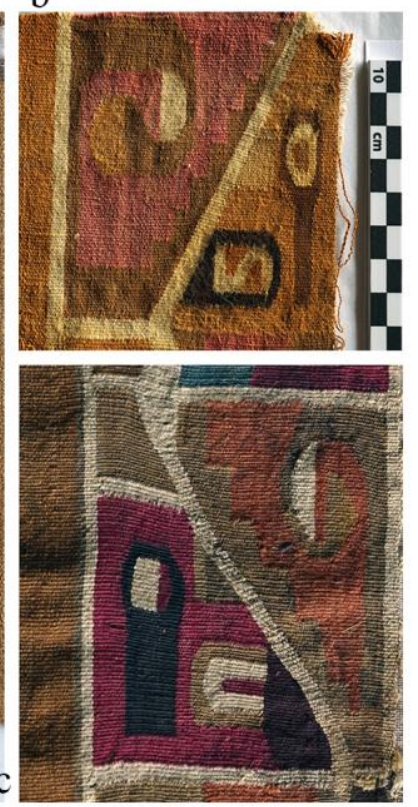

Figure 7. Fragments of three Wari Tapestry tunics in the 'Face-fret' style. (a) CS1282. (b) CS1283. (c) CS1569.The cotton warps are horizontal, the wefts vertical as when worn. Photos (a) Alex Bryce, (b) and (c) A. H. Peters.

On the tapestry surface of our container the images are all similarly proportioned, but the tube provides a foreshortening effect: the same range of motifs present in the Wari tunic bands are here arrayed on a cylinder, vertical when held with its open end upwards. The tapestry is,

\footnotetext{
${ }^{15}$ Wilhelm Reiss and Alfons Stübel, The Necrópolis of Ancón in Perú. A. H. Keane, transl. (Berlin: A. Asher, 18801887). See plates 16 and 17. http://pds.lib.harvard.edu/pds/view/13890340

${ }^{16}$ Susan E. Bergh, "Tapestry-woven tunics," In S. E. Bergh (ed.) Wari, Lords of the Ancient Andes, (Cleveland: Cleveland Museum of Art and New York: Thames and Hudson, 2012), 158-191. Also see Alan Sawyer,

"Tiahuanaco Tapestry Design," Textile Museum Journal Vol. 1 No. 2 (1963), 27-38.
} 
however, oriented perpendicularly to that of the Wari tunics and rather different in structure. The warp elements are fine straight splints of wood parallel to the cylinder beneath. They can be seen where certain wefts have deteriorated, probably due to the dye processes used to achieve each color. The camelid wefts interlace these wood splints, often turning back as in slit tapestry and only occasional interlocking with adjacent wefts of a different color. This differs from the systematically interlocked wefts in the tapestry bands of Wari tunics.

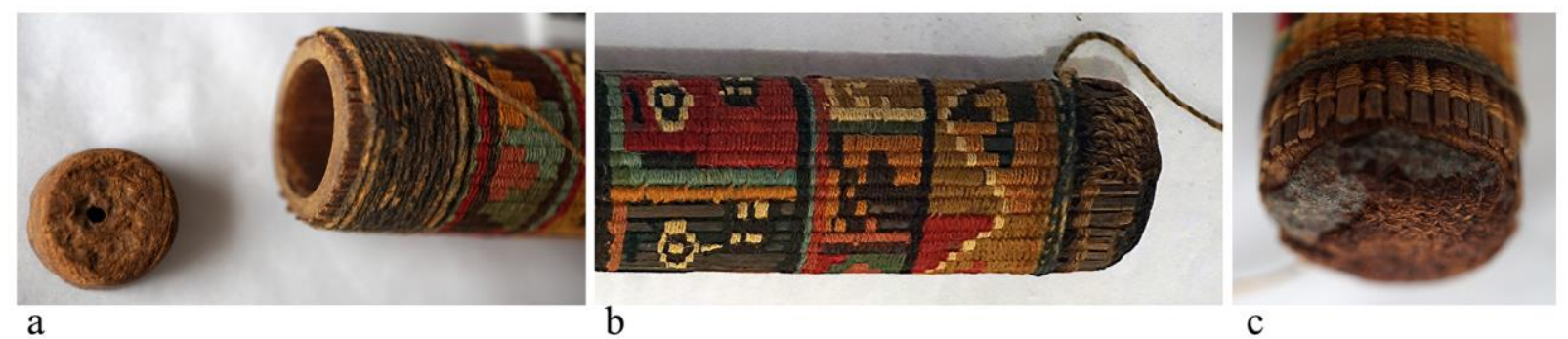

Figure 8. Details of the ends of the wood splints, interlacing yarns and binding cords at: (a) the opening of the tube with the drilled cork that capped it; $(b)$ and $(c)$ the base of the tube, covered with a pad of resin and a spiral-looped camelid cloth. Photos A. H. Peters.

At each end of the tube, the wooden splints are bound by cotton yarns, tighter in spin and ply than the camelid wefts (Fig. 8). On the closed end of the tube, the ends of the splints show slight irregularities, though they have been neatly cut to size by a sharp blade. About a centimeter of plain-weave interlace features paired fine S-plyed yarns, yellow ochre in color, and above them three passes of a heavier Z-plyed yarn coated with a dark brown resinous material. The closed end of the tube is also covered with a thick pad of resinous material, creating a slightly domed surface covered by a disk of looped dark brown camelid hair that has been pressed onto the pad when it was still flexible. The fiber, spin and ply look quite different from the yarns used in the tapestry weave. In a small area we can see how this looped covering once extended over the base of the splints and under the binding yarns.

Adjacent to the open end of the tube, a wider binding of resin-coated Z-plied cotton yarns may cover fine interlacing like that of the other end. In some places, the ends of the wooden splints show use polish. Here we can more clearly see the cylinder's material, thickness and interior, whose regular surface suggests it has been cut from a segment of heavy cane, larger and thicker than the arrow cane (Gymnerium sagittarium) found along riverbanks and large irrigation canals of the Ica region. The only native cane of this size in the central Andes is a mountain bamboo, Chusquea scandens, which grows widely in the well-watered forests of the eastern Andean slopes between 2500 and 3500 meters above sea level - quite a distance from Ica. The center of this cane is usually not hollow, but its vascular structure could facilitate the carving of a smooth surfaced tube, while its segmented structure can facilitate a strong closure at the base.

The combination of camelid hair and cane splints occurs in other Middle Horizon artifacts. Small panels woven of canes and camelid hair, with cotton binding yarns, have been found hanging on the outer surface of Middle Horizon mummy bundles at Huaca Malena and other Central Coast sites. ${ }^{17}$ On discussing our tubular tapestry container with colleagues prior to and during the TSA

\footnotetext{
${ }^{17}$ Rommel Angeles Falcón, personal communication (2020).
} 
conference, we learned that components of similar artifacts, as well as more complete examples, exist in museums in Peru, Chile and the United States.

The Amano Museo Textil Precolombino in Lima, Peru holds a panel woven of wooden splints interlaced with camelid yarns in a tapestry structure, similar in its components, structure and proportions to the exterior surface of our tube. It appears to be the outer layer of this type of artifact, either separated from or not yet attached to the cane substrate. The imagery is simpler, composed of circumferential bands containing either a series of stepped lozenges or a series of rectangles divided on a diagonal axis into two contrasting colors. The rectangles are regularly divided on the axis of the tube into six registers, creating a grid, but the lozenges do not align with this pattern. A wide range of colors are present, though, as in our other examples, many yarns have disappeared. This piece demonstrates that the tapestry structure was woven as a rectangular panel with warps of wood splints and camelid wefts, then wrapped around and affixed to a tube.

The Museo Chileno de Arte Precolombino, has a more complete example of this type of tube (MChAP cat. 3449) with late Middle Horizon imagery. ${ }^{18}$ Two wide circumferential registers depict elements of griffon-like figures and a 'crowned' profile head, similar to motifs found on Wari four-cornered hats. Another register by the tube opening repeats diagonally bisected rectangles. The divisions among motifs along the axis of the tube do not coincide. This tube preserves a protective pad at its closed end, where resin-coated cotton cords have been wrapped diagonally in a complex binding pattern. The open end preserves a gourd cap with a biconical perforation, typical of those made with sharp flaked stone or metal tools in prehispanic times. A thick white cord looped to the adjacent cotton binding and S-plied probably once was attached there. This tube was found to contain long, thin cactus spines. Not perforated as needles, these have been considered possible paraphernalia for taking hallucinogenic snuff.

The Fowler Museum of Cultural History at UCLA holds a similar tube (cat. X86.2397), published by Phipps. ${ }^{19}$ Its surface layer resembles the Amano panel in its layout, technical features and the range of colors present. It has been considered Nasca in style. The circumferential registers and those along the axis of the tube are regularly divided, creating a grid of rectangles bisected by a sequence of diagonal stepped lines in various colors. These alternate in slope direction, creating a rainbow-like effect as well as a zigzag pattern around the circumference of the tube. This tube was allegedly found within a skin pouch. It conserves a cap and contained finely perforated cactus spine needles and other cactus spines, leading to its interpretation as a needle case.

The Art Institute of Chicago holds a tubular container (ARTIC cat. 1955.2667) with features closely related to our example, as well as others which are unique. Its ten circumferential bands include four with similar profile animal heads resembling to the "Camelid Sacrificer" and a narrower band of profile animal heads, also probable camelids. One band contains profile heads of a raptorial bird, while two repeat the meander motif ( reca) characteristic of Middle Horizon

\footnotetext{
${ }^{18}$ Carole Sinclaire Aguirre, "Wari y Tiwanaku: Los tejidos imperiales," In C. Sinclaire, ed. Awakhuni, (Santiago: Museo Chileno de Arte Precolombino, 2006), 55.

${ }^{19}$ Elena Phipps, The Peruvian Four-Selvaged Cloth: Ancient Threads, New Directions, (Textiles Series 12), (Los Angeles: The Fowler Museum, University of California, 2013).
} 
imagery. One narrow band simply alternates squares in two colors, while that adjacent to the tube opening consists of rectangles in two colors divided by a white diagonal line. The motifs are not aligned consistently along the axis of the tube. A Z-plied cord coated with a black resinous material binds the top and bottom and a complex S-plied cord (repaired) links the tube to its cap. We thank our colleagues at ARTIC for sending us photos and look forward very much to studying this container in detail when research visits again become possible.

These comparisons teach us much about the nature of our decorated tubular container. The tapestry structure covering its outer surface was woven on wood splints to create a rectangular panel, then wrapped around the tube and bound to it. This weaving practice links to the creation of panels woven on cane splints that were placed on the exterior of Middle Horizon mortuary bundles. Our tube once probably had a fiber-bound padded base like that of MChAP cat. 3449, now absent. Yet this loss has allowed us to examine the resinous pad and looped camelid hair cover beneath, which may provide data useful for study of the other containers. Our tube probably had a perforated gourd cap and attached cord, though these have been lost: the person who perforated a cork replacement cap may well have seen one of the other tubes.

Emblematic Middle Horizon imagery also characterizes most of this larger group, and similar features shared by all suggest that this artifact type, like Wari tunics and four-cornered hats, symbolized social roles and practices linked to the relationships that forged imperial power. Placement of our tube in a larger comparative group highlights the unusually close relationship between its imagery and that of a particular genre of Wari Tunic. Did it hold cactus needles used to stitch the seams and edge finishes of those high-status tunics, or paraphernalia for taking hallucinogenic snuff in events that forged lasting alliances among ritual and political leaders?

Plants in the tapestry, more questions:

Legacy collections like this one formed in Ica in the early $20^{\text {th }}$ century can provide information that mediates between the disturbed fragments and occasionally well-preserved contexts recovered archaeologically in heavily looted sites and other objects from the region that have passed through many hands and are widely scattered in museum collections. Detailed formal comparisons allow us to propose that an artifact was created by persons who lived or travelled in particular places, or that a group of artifacts must be linked to the same production community even if its geographic coordinates are as yet unknown. Archival studies and isotope analysis may produce further information to support - or not - our hypotheses regarding the geographic provenance of artifacts in a collection, while AMS carbon dating of textile fibers has growing potential for linking a particular style to historic time.

It is unsurprising that research amid a pandemic should leave us with new questions and inquiries still in process. Direct analysis of all the artifacts compared will permit us to evaluate the degree of similarity in their materials and techniques. We look forward to work with the botanists to further define plant species that have been used, along with cotton fiber and camelid hair, to create these artifacts. Pursuing the use of plant elements in these tapestry structures leads us to connect their analysis to that of diverse other types of artifacts created with analogous materials. Hypotheses regarding the plant species lead us to consider a widening range of environmental contexts and ecological relations, as well as travel through Andean landscapes linked to producing and procuring botanical resources. 
The band of feline figures embodies long-distance relationships between the Paracas peoples and their southern neighbors. Its imagery takes us to rock art inscribed more than two thousand years ago along the travel route between the coast and adjacent highlands of the Chuquibamba region. Much later, in the time of the Inka empire, textile exchange and influence again marks a particularly close relationship between this region and that of Ica. The presence of reeds in the tapestry embodies the importance of wetlands, found both near the sea and in the high puna regions - the preferred habitat of the vicuña and alpaca that provide the fine hair spun and dyed to create the rest of the tapestry. Historically and today, the puma is both a terrible threat to unwary camelids - among others - and a symbol for the fierce wisdom required of human leadership. The smaller wild cats are less prominent in mythic discourse but clearly played important social, as well as ecological, roles in the past.

The Wari tubular container embodies a very different social context, approximately a thousand years later. Its component yarns dyed in a wide range of hues appear also to come from different spinners, indicating larger-scale relations of production. The bamboo tube must have traversed the Andean cordillera to be combined with camelid hair from the highlands and cotton from lowland valleys, indicating far-flung networks of travel and exchange. The wood splints could be made from the straight-fibered bamboo, but preliminary examination suggests a different arboreal source. The source of the resinous material provides another challenge and opportunity. Comparison with other examples of this artifact type establish that it is a well-defined special purpose container with standard features. All these containers are linked to high-status, ritually charged imagery, and our tapestry tube is one of the more explicit cases. We are left with another question: is the tapestry-wrapped container an item of regional importance whose imagery was inspired by the Wari tunics, or might the foreshortened tunic bands be inspired by this type of tubular artifact?

Exploring artifacts with unusual features can open new topics in Andean archaeology and further demonstrate the power of textiles to shed light on ancient practices and social relationships.

\section{Acknowledgements:}

Our research has been made possible by the patience and support of members of the Soldi family, including the original collectors and long-term conservators, Carlos and Ana Maria Soldi. Development of our analysis and interpretations was nourished by ideas and data shared by friends and colleagues: Jorge Recharte, Jessica Lévy, Verónica Cereceda, Maria Elena del Solar, Soledad Hoces de la Guardia, Bárbara Cáses, Rommel Ángeles Falcón, and Yuki Seo. For comparisons with artifacts excavated at the Paracas site, we thank the Museo de Sitio de Paracas, Museo Regional de Ica, Museo Nacional de Antropología, Arqueología e Historia del Perú and Peru's Ministry of Culture for research and photography permissions (2012-2017). This research has received support from the National Science Foundation (BCS 0852151, 2009-2013) and a Dumbarton Oaks Fellowship in PreColumbian Studies (2006-2007). On presenting at the 2020 Biennial Symposium of the Textile Society of America, our preliminary observations were enriched by the comments and comparisons offered by Elena Phipps, Andrew Hamilton and Elizabeth Pope. We thank TSA for creating an on-line forum that has fostered scholarship and the exchange of insights at a time when we are unusually isolated from both museum collections and our professional worlds. 


\section{Bibliography}

Aguirre, Carole Sinclaire. "Wari y Tiwanaku: Los tejidos imperiales," In C. Sinclaire, ed. Awakhuni. Santiago: Museo Chileno de Arte Precolombino, 2006.

Bergh, Susan E. "Tapestry-woven tunics," In S. E. Bergh (ed.) Wari, Lords of the Ancient Andes. Cleveland: Cleveland Museum of Art and New York: Thames and Hudson, 2012, 158-191.

Boucherie, Nathalie, Witold Nowik, and Dominique Cardón, "La producción tintórea Nasca: nuevos datos analíticos obtenidos sobre textiles recientemente descubiertos en excavaciones." In S. Desrosiers and P. Nuñez-Regueiro, eds. Textiles amérindiens. Regards croisés sur les couleurs. Mundo Nuevo - Nuevos Mundos, Colloques [en ligne] 2016.

https://journals.openedition.org/nuevomundo/69222\#text

Frame, Mary. "Motion Pictures: Symmetry as animator, classifier and syntax in the Nasca embroideries of Peru," In D. K. Washburn and D. W. Crowe, eds. Symmetry Comes of Age: The Role of Pattern in Culture. Seattle: University of Washington Press, 2004, 133-176.

Guaman Poma de Ayala, Felipe. El primer nueva corónica y buen gobierno (1615/1616) (København, Det Kongelige Bibliotek, GKS $22324^{\circ}$ ) http://www5.kb.dk/permalink/2006/poma/info/en/frontpage.htm

Haeberli, Joerg. "Tiempo y tradición en Arequipa, Perú y el surgimiento de la cronología del tema de la deidad central," In P. Kaulicke and W. H. Isbell, (eds.), Huari y Tiwanaku: Modelos vs. Evidencias (segunda parte). Boletín de Arqueología PUCP 5 (2001), 89-137.

Jennings, Justin, Maarten Van Hoek, Willy Yépez Álvarez, Stefanie Bautista, Ronald A. San Miguel Fernández, and Giles Spence-Morrow. "Illomas: The three-thousand year history of a rock art site in southern Peru." Nawpa Pacha 39, No. 2 (2019), 181-211.

King, Mary Elizabeth. Textiles and Basketry of the Paracas Period, Ica Valley, Peru. PhD. Dissertation, Department of Anthropology, University of Arizona, Tuscon (Ann Arbor: University Microfilms, 1965).

Kroeber, Alfred L. and William D. Strong. "The Uhle Pottery Collections from Ica, with Three Appendices by Max Uhle." University of California Publications in American Archaeology and Ethnology Vol. 21, No. 3 (1924), 95-134.

Peters, Ann H. "Travels of a rayed head: textile movement and the concepts of center and periphery in the southern Andes," In W. Isbell, M. Uribe, A. Tiballi and E. P. Zegarra, eds. Images in Action: The Southern Andean Iconographic Series. Los Angeles: Cotsen Institute of Archaeology Press, University of California, 2018, 109-138.

Phipps, Elena. The Peruvian Four-Selvaged Cloth: Ancient Threads, New Directions, (Textiles Series 12). Los Angeles: The Fowler Museum, University of California, 2013. 
Ramirez, Dámaso. "Asunción Cano Estado de la diversidad de la flora vascular de los Pantanos de Villa (Lima - Perú)," Revista Peruana de Biología Vol. 17, No. 1 (2010), 111-114.

https://sisbib.unmsm.edu.pe/BVRevistas/biologia/v17n1/contenido.htm

Reindel, Marcus and Johny Isla. "De Paracas a Nasca: Nuevas evidencias desde la vertiente occidental de la sierra de Lucanas, Ayacucho.” Boletín de Arqueología PUCP 25 (2018), 229254. http://revistas.pucp.edu.pe/index.php/boletindearqueologia/article/view/21525

Reiss, Wilhelm and Alfons Stübel. The Necrópolis of Ancón in Perú. A. H. Keane, transl. (Berlin: A. Asher, 1880-1887). See plates 16 and 17.

http://pds.lib.harvard.edu/pds/view/13890340

Roque, José Y. and Ella Karina Ramirez. "Flora vascular y vegetación de la laguna de Parinacochas y alrededores (Ayacucho, Perú)," Revista Peruana de Biología Vol. 15, No. 1 (2008) 61-72. https://sisbib.unmsm.edu.pe/BVRevistas/biologia/v15n1/contenido.htm

Tello, Julio C. Paracas: Primera parte, (Lima: Institute of Andean Research, 1959). 